\title{
Impacts of Mineralogy and Competing Microbial Respiration Pathways on the Fate of Uranium in Contaminated Groundwater
}

\author{
Kostka, Joel E. \\ Florida State University
}

RESULTS TO DATE: SUMMARY OF OBJECTIVES AND APPROACH: This is a field-oriented project designed to elucidate the microbiological and geochemical factors controlling $\mathrm{U}(\mathrm{VI})$ reduction / immobilization in subsurface environments at the NABIR FRC. Efforts focused on acidic sediments, 1) to characterize the dominant minerals likely to limit $U$ speciation, 2) to directly quantify microbial respiration processes controlling $U$ subsurface chemistry, and 3) to identify and enumerate the responsible organisms. Results indicate that the activities and growth of bacteria are limited in this acidic subsurface. The relevant geochemical parameters have now been characterized, and respiration rates quanitfied. This work is resulting in three publications

DELIVERABLES: INVITED TALKS: ?Impacts of Mineralogy and Competing Microbial Respiration Pathways on the Fate of Uranium in Contaminated Groundwater,? DOE-NABIR Principal Investigator Meeting, March 18th, 2002

?Microbial reduction of Fe(III) bound in clay minerals: laboratory investigations of growth and mineral transformation,? 223rd American Chemical Society National Meeting, Division of Geochemistry, April 8th, 2002

MEETING PRESENTATIONS: J.E. Kostka, H. Skelton, D. Dalton. Growth of Shewanella oneidensis on smectite as the sole electron acceptor. 2001 Annual Meeting of the American Society for Microbiology, Orlando, FL.

D. Dalton, J. E. Kostka, G.R. Drake, K. Scheinemann, and D.L Balkwill. Gram positive, dissimilatory $\mathrm{Fe}$ (III)-reducing bacteria isolated from agricultural soils and subsurface sediments. 2001 Annual Meeting of the American Society for Microbiology, Orlando, FL.

GR Drake, JE Kostka, D Dalton, K Scheinemann, and DL Balkwill. Diversity of dissimilatory Fe(III)reducing bacteria from soils and subsurface sediments, 2001 Annual Meeting of the International Society of Microbial Ecology, Amsterdam, Netherlands.

L. Petrie, J. E. Kostka, S. Dollhopf, N. North, and D. L. Balkwill. Assessment of Iron(III)- and SulfateReducing Microbial Communities and their Impacts on Uranium Reduction, DOE-NABIR Principal Investigator Meeting, March, 2002

J. E. Kostka, L. Petrie, S. Dollhopf, N. North, D. L. Balkwill. Enumeration and characterization of Fe(III) and $\mathrm{U}(\mathrm{VI})$-reducing bacteria in subsurface sediments from the U.S. DOE-NABIR Field Research Center (FRC) at Oak Ridge, Tennessee. 2002 Annual Meeting of the American Society of Microbiology, Salt Lake City, UT, 20-25 May

H. Dong and J.E. Kostka. Microbial transformation and dissolution of smectite clay minerals. 2002 Annual Meeting of the Clay Minerals Society, Boulder, CO, June.

PUBLICATIONS: J.E. Kostka, D. Dalton, G.R. Drake, K. Scheinemann, D.C. White, A.D. Peacock, and D.L. Balkwill. 2002. Gram positive, dissimilatory Fe(III)-reducing bacteria isolated from subsurface sediments and agricultural soils. Applied and Environmental Microbiology (submitted). J.E. Kostka, D. Dalton, H. Skelton, S. Dollhopf, and J.W. Stucki. 2002. Growth of iron(III)-reducing bacteria on clay 
minerals as the sole electron acceptor and a growth yield comparison on a variety of oxidized iron forms. Applied and Environmental Microbiology (submitted). 